\title{
TERRITORIAL SOCIETIES FEATURES: EUROPEAN EXPERIENCE
}

\author{
Irina Popova ${ }^{1}$, Nataliya Demchenko²
}

\begin{abstract}
The purpose of the article is to summarize the experience of developing tools for the implementation of amalgamated territorial communities. The European countries' experience helps to improve the system of public administration in such a way that it acts in the interests of the individual-citizen and is under the control of civil society. The important factors in the dynamic development of the state is effective public administration at all levels of the administrative and territorial structure of the country are investigated. The main links in this section are the district and regional levels, within which the main socio-economic, political and cultural links are realized and estableshed. The main task of effective regional public administration is to ensure the socio-economic development of the region and to meet the needs of citizens. Methodology. The survey is based on a comparison of data from the EU countries. The competences of local governments in the EU countries are examined. Results. Implementation tools for amalgamated territorial communities have been identified to assess the socio-economic development of the community for investment attractiveness. It has been proved that the amalgamation of territorial communities should be based on the principle of multicriteria, since the main participants in the formation, functioning and further development of the community are people who are united in a team to achieve a common goal, which is to develop the territorial community in order to improve the quality of life. Practical implications. Society will be able only if each of its members clearly understands the possibility of improving the standard of living within the community than existence outside of it. The study has shown that there are the number of criteria, including spatial, temporal, demographic, labor, cultural, historical, financial, that should be considered when amalgamating territorial communities. It is proved that the main instruments of implementation of amalgamated territorial communities are area, population (including demographic structure), income level, level of spending, financing structure, structure of economic entities by types of activity and level of income, number of objects of social infrastructure, employment and community unemployment, etc.
\end{abstract}

Key words: amalgamated territorial community, implementation, tools, criteria, communes, municipalities.

JEL Classification: R13, R50

\section{Introduction}

One of the most important factors of modern state-building in Ukraine is the improvement of the system of public administration at all levels of the administrative and territorial structure of the country. The main task of effective regional public administration is to ensure the socioeconomic development of the region and to meet the needs of citizens. Thus, in exploring the world experience and taking into account the domestic practice of public administration, it is necessary to improve the system of public administration in such a way that it acts in the

\footnotetext{
Corresponding author:

${ }^{1}$ National University of Pharmacy, Ukraine.

E-mail: ira_popova_dik@ukr.net

ORCID: https://orcid.org/0000-0003-2962-9040

${ }^{2}$ National University of Pharmacy, Ukraine.

E-mail: demchenata@ukr.net

ORCID: https://orcid.org/0000-0001-5915-0087

ResearcherID: D-2228-2015
}

interests of the individual-citizen and is under the control of civil society.

The study of decentralization of public power has received considerable attention from both domestic and foreign scientists. Thus, in the works of Zablodskaya I.V., Boychenko E.B., Grechana S.I. much attention was paid to monitoring the implementation of the strategy of the amalgamated territorial communities; Ustimenko V.A., Dzhabrailov R.A. deal with issues of legal support for the development of territorial communities; Primush R.B., Gochachilov K.M., Lotsyuk and others considered tools for the development of 
territorial communities; Seryugin S.M., Sharov Yu.P., Goncharuk N.T. explored innovative approaches and tools for managing the development of integrated territorial communities (Ghrechana, 2017). However, despite the regulatory framework for the Ukrainian and foreign scientists, the processes of decentralization and organizational support remain poorly understood. The European experience needs special study, especially in the development of the Amalgamated Territorial Communities (ATC) implementation tools.

The system of sovereign governance is the basis for the development of democracy. Consciousness of Ukraine is an important factor in the current stage of state creation in Ukraine. The complication of the current process of establishing an effective system of sovereign governing is that of feeling guilty of the interest in the environment of the huge individual, who has been controlled by the control of enormous suspension.

An important factor in the dynamic development of the state is effective public administration at all levels of the administrative and territorial structure of the country. The main links in this section are the district and regional levels, within which the main socio-economic, political and cultural links are realized. The main task of effective regional public administration is to ensure the socio-economic development of the region and to meet the needs of citizens. The degree of effective local selfgovernment is one of the defining criteria for the democracy of the political system. The imperfection of local government in Ukraine, its inconsistency with the European standards and principles, necessitates the search for ways to reform. Ukraine, like most countries of the former Soviet Union, is in the process of further improving its governance system, including territorially. That is why studying the problems and ways of solving them in forming the system of territorial governance in the countries of Western Europe is considered as an important component of the transformation processes, especially in view of our country's desire for European integration. Any reform in the country of learning and using the experience of other countries is a prerequisite for successful reform. In particular, clarifying the objective patterns and basic principles of centralized and decentralized governance should help Ukraine avoid many mistakes and difficulties in developing a modern governance model based on a combination of different degrees of centralization and decentralization.

\section{The European standards and principles in communes' management}

One of the defining criteria for the democratic system of the political system is the effective activity of local self-government. The imperfection of local government in Ukraine, its inconsistency with the European standards and principles, necessitates the search for ways to reform. In carrying out any reforms in the country, the study and use of the experience of other countries is a prerequisite for successful reform. In particular, elucidation of the objective laws and basic principles of centralized and decentralized management should help Ukraine avoid many mistakes and difficulties in the development and formation of a modern management model based on a combination of different degrees of centralization and decentralization.

One of the main and urgent tasks of democratization of social and political life in Ukraine is reforming the system of local selfgovernment, as it is one of the most important elements and indicators of democratization of society. In the current context of intensifying the processes of decentralization, the national economy has been challenged to form territorial associations that would function effectively and develop comprehensively. Studying the experience of European countries, it has been determined that territorial entities have different names. So, these are gminas in Poland; communes in France, Belgium, Italy, Sweden; municipalities in Spain, Great Britain; communities in Germany.

The main task of the commune is to meet the most important human needs. Gmina is endowed with: the status of a legal and independent entity in the performance of its own tasks; carrying out its functions has own and additional income (in the form of subventions); it is empowered with ownership of communal property; judicial protection is provided for the protection of its independence (Dolecjkyj, 2001).

Communities include: public education (elementary schools and high schools); street lighting; water supply, sewerage, etc.; communal housing construction; landscaping; culture, including community libraries and other cultural institutions, and the protection of historical and cultural monuments; public order and citizens' safety, as well as fire and flood protection of the commune road, streets, bridges, squares and traffic management; management of real estate, 
environmental protection and water management; local public transport; healthcare social assistance and its infrastructure; markets and market premises; commune cemetery.

The functioning of both legislative and executive structures is envisaged in the commune's territory. The main representative political and legal body of the commune is the commune council. The main powers of the councils are focused on budget approval, development strategies (programs), property management, and more. For the more efficient performance of their functions, communes can form auxiliary units of management - saleseries (at the level of rural communes), settlements (in communes of urban and rural origin) and districts (in cities) (Lendjjel, 2011).

Communes operating in France, Belgium, Italy, Sweden significantly differ in size and population. Thus, in $90 \%$ of the communes the population is less than 2000 citizens. The number of communes in France is about 36,700, and the average population is 380 people. The commune is the only administrative and territorial unit where there is no separate independent state authority, that is, in theory, the mayor in his/her own person combines municipal functions and functions of state power. However, many functions of the state executive power belong to the functions of local self-government. That is, the commune is an autonomous collective on the territory. Legal indicators characterizing a commune are its name, territory and population.

In Italy, there are 110 provinces and 8048 communes, however, the number of communes is not constant, because communes can unite and separate based on the interests of their inhabitants (and this practice is quite common). In Italy, a commune is characterized by: population and territory. The Italian commune has the right to issue binding administrative acts. The Italian law states that a commune is an organization that is endowed with independence and autonomy and has its own charter. The Italian commune is also endowed with legal personality. The competence of the communes includes: the right to impose and accumulate local taxes, regulate local police activity, health and social services at local level, primary and secondary education, public transport, garbage collection and recycling, street lighting, trade permits (NADU, 2012).

Local government in Spain is the third level of a multi-level government system. The main criterion for the formation of the municipality is the territory (taking into account the population). All municipalities carry out the following functions: lighting, disposal, waste removal, cleaning of forks, water supply, food quality control. If the number of a municipality is from 5000 to 20000 , it also provides services for the maintenance of parks, libraries, waste removal and market space management. In the number from 20000 to 50000 people civil and fire protection services and sports services are additionally provided. With the number is more than 50000 , in addition to the above powers, it provides services in the operation of public transport and environmental protection (Fedorenko, 2017).

In Germany, as in Ukraine, the territorial community is the primary subject of local selfgovernment. The community has the exclusive right to solve local problems within the framework of the national legislation, the community is recognized as "territorial corporations", and the issue of their income is regulated. Criteria in the process of determining a territorial community are the population, settlement structure, traditions, features of historical, social development of cities, etc. The number of communities in Germany is $12312,16 \%$ of which are independent communities and $77 \%$ belong to a two-tier union of communities (Shymanke, 2008).

It should be noted that the administrative and territorial units, despite their different names, have the same functional purpose: the level and quality of life of people in the community should be higher than separately from it.

For the successful accomplishment of its mission, each ATC must have certain criteria that contributed to its formation. In the national economy, the basis of community formation is the territorial-spatial principle according to which, the distance from the administrative center of the community to the outermost settlement should not exceed 20 kilometers (although in the realities of the region it may be more); Emergency medical and firefighter arrivals within the community should not be more than thirty minutes; school (minimum 250 pupils), kindergarten (number of preschool children in the administrative center should not be less than 100).

It should be noted that, for ease of analysis of statistics, the EU carries out grouping using the single-criterion principle. The main criterion is the population. This system is called NUTS 
(Nomenclature of Territorial Units for statistics), a nomenclature of territorial units for statistics. The purpose of this grouping is to solve the following tasks: collection, harmonization, development of regional statistical information in the EU countries; socio-economic analysis of regions at different levels; shaping the EU regional policy (Ustawa, 1990).

\section{Community integration criteria in the national economy}

If we consider the EU countries separately, it should be noted that the amalgamation of territorial communities is based on the principle of multicriteria.

Criteria for determining the feasibility of community formation in Germany are population, settlement patterns, traditions, features of historical, social development of cities, and so on. However, there are significant differences between communities, that is, each is unique, which necessitates a proper management organization depending on the characteristics of the community. Exploring the commune as an organization, B. Metcalfe (Metcalf, 1996) distinguishes its following features: the great importance of the group, not of the nuclear family; "joint money and expenses"; collective home ownership; group decision making both in general and in personal matters.

The need to use the principle of multicriteria defines the approach based on several criteria (Pautova, 2011):

- determination of the optimal number of the population, taking into account the number of ablebodied, its growth, employment rates, migration, etc.;
- ensuring economic proportionality in the union between economically developed and depressed settlements;

- identification of socio-economic and cultural centers;

- defining the boundaries of amalgamation on the principle of continuity of boundaries of existing regions, territories of settlements, objects of industry.

On the basis of the above, we can form a system of criteria for ATC as a synthesis of national characteristics and foreign experience (Table 1).

Table 1 shows that there are a number of criteria, in particular spatio-temporal, demographic, labor, cultural and historical, financial. Of course, taking the entire system of criteria into account when amalgamating territorial communities is an extremely difficult task.

However, it should be noted that only with as many criteria as possible a synergistic effect can be achieved. It allows the energy of the communities that have defined their position to be fully supported. After all, the main goal of local government reform is to organize people around their places of residence in such a way as to facilitate their joint activity, while improving the standard of living and quality of life for all members of the community.

\section{Assessment criteria of territorial communities}

The assessment of the capacity level of territorial communities is made on the basis of assessment criteria, taking into account the limit values, which

Table 1

The system of community integration criteria in the national economy

\begin{tabular}{|c|c|}
\hline Criteria & Content \\
\hline \multicolumn{2}{|r|}{ Available } \\
\hline Spatial & $\begin{array}{l}\text { The distance from the administrative center of the community to the outermost settlement should } \\
\text { not exceed } 20 \text { kilometers }\end{array}$ \\
\hline Temporal & Emergency medical and firefighters should arrive within the community for no more than 30 minutes. \\
\hline Social objects & $\begin{array}{l}\text { Presence of school (not less than } 250 \text { pupils), kindergarten (number of preschool children in the } \\
\text { administrative center should not be less than } 100 \text { ) }\end{array}$ \\
\hline \multicolumn{2}{|r|}{ Additional } \\
\hline Demographic & $\begin{array}{l}\text { The population, for example, in the EU, cannot be less than } 2500 \text {; for rural community }-8500 \text {; } \\
\text { settlement - 15 600, urban - } 33700 \text { and more; density, settlement pattern, growth, migration. }\end{array}$ \\
\hline Labor & Number of able-bodied population, employment rate, unemployment rate, wage rate. \\
\hline Cultural and historical & Traditions, features of historical development, historical connections between particular territories. \\
\hline Financial & $\begin{array}{l}\text { The ratio of own revenues (for example, in the EU, the amount of own revenues is at least } 50 \% \text { of the } \\
\text { estimated need) and costs, level of subsidy, income and expenses per person. }\end{array}$ \\
\hline Proportional & The ratio of economically developed areas to depressed ones. \\
\hline
\end{tabular}


Table 2

The level of ability of ATC

\begin{tabular}{|c|c|c|c|}
\hline The criterion of evaluation & Indicator & The numerical value & Level of ability \\
\hline \multirow{3}{*}{ Population } & p to 3000 inhabitants & 0,3 & Low \\
\cline { 2 - 4 } & from 3000 to 5000 inhabitants & 0,6 & Average \\
\cline { 2 - 4 } & more than 5000 inhabitants & 1 & High \\
\hline \multirow{3}{*}{ Square } & up to $200 \mathrm{~km}^{2}$ & 0,3 & Low \\
\cline { 2 - 4 } & from 200 to $400 \mathrm{~km}^{2}$ & 0,6 & Average \\
\cline { 2 - 4 } & more than $400 \mathrm{~km}^{2}$ & 1 & High \\
\hline \multirow{3}{*}{ Taxability Index } & to 0,3 & 0,3 & Low \\
\cline { 2 - 4 } & from 0,3 to 0,9 & 0,6 & Average \\
\cline { 2 - 4 } & more than 0,9 & 1 & High \\
\hline \multirow{3}{*}{ Share of local taxes and fees } & up to $10 \%$ & 0,3 & Average \\
\cline { 2 - 4 } & from $10 \%$ to $20 \%$ & 0,6 & High \\
\cline { 2 - 4 } & more than $20 \%$ & 1 & \\
\hline
\end{tabular}

are: population is 3000 people; area is $200 \mathrm{~km}^{2}$; taxability index is 0,3; the share of local taxes and fees is $10 \%$. The ability level depends on the value of the indicator, which reflects a certain criterion of evaluation (Table 2).

Generalization of the European experience in the functioning of ATC has led to the following conclusions regarding the tools for their implementation:

1. The size of the commune/population directly affect the number of staff of the management apparatus: with the increase in population increases the staff of management (more than 10,000 inhabitants of rural communes are more than twice as large as rural communes with a population of up to 6000 , similarly, more than
20000 inhabitants of rural communes have twice the number of rural communes with a population of up to 10000 of inhabitants) (Figure 1).

2. Social assistance centers, houses of culture and libraries typical of all types of communes; in the vast majority of communes there is an economic and administrative department of education which is not part of the administrative apparatus.

In smaller gminas (with a population of up to 6,000), educational functions fall within the authority of the management apparatus; in most rural communes with a population of more than 6000 inhabitants and rural-urban communities with a population of more than 10000 residents, communal facilities operate, in smaller communes the powers in the communal sector are vested in the

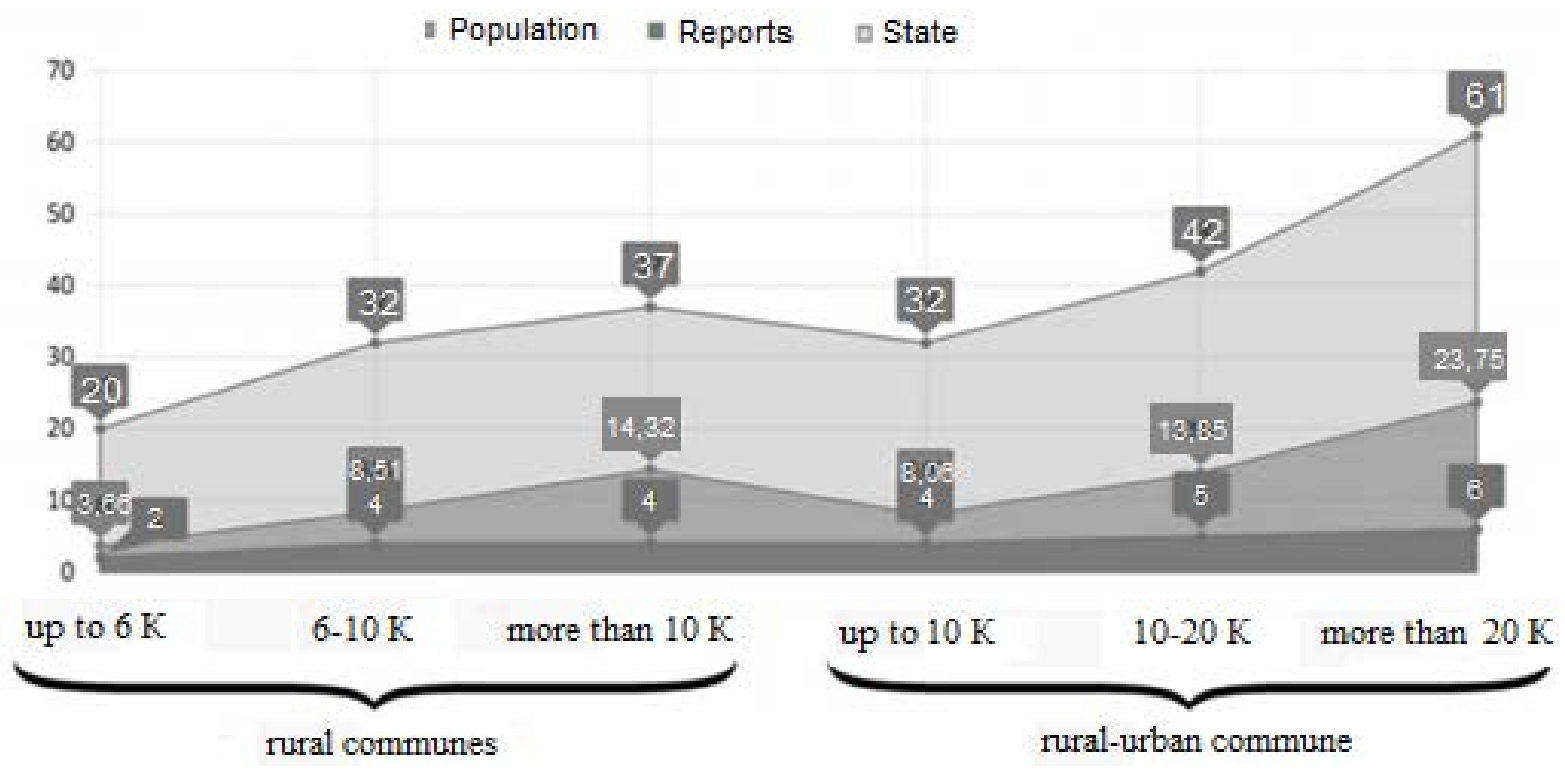

Figure 1. Indicators of gmina management apparatus 
administration apparatus; most rural communities with a population of more than 6000 residents operate independent public health facilities; and in rural-urban communes with a population of more than 20000 inhabitants there are stationary selfhelp homes and centers of sports and recreation (Figure 2).

3. Analysis of the structure of own current expenditures of the commune's budgets revealed that the major part of these financial resources is directed to the financing of administrative units, educational establishments, social assistance centers, cultural centers and libraries. At the same time, as the population grows, the share of expenditures on the administrative unit of the commune decreases, and, as a rule, expenditures in the sphere of education increase (Figure 3 ).

\section{Findings}

Based on the conducted research, we can conclude that ATC should be based on the principle of multicriteria, which promotes the development of the territorial community in order to improve the

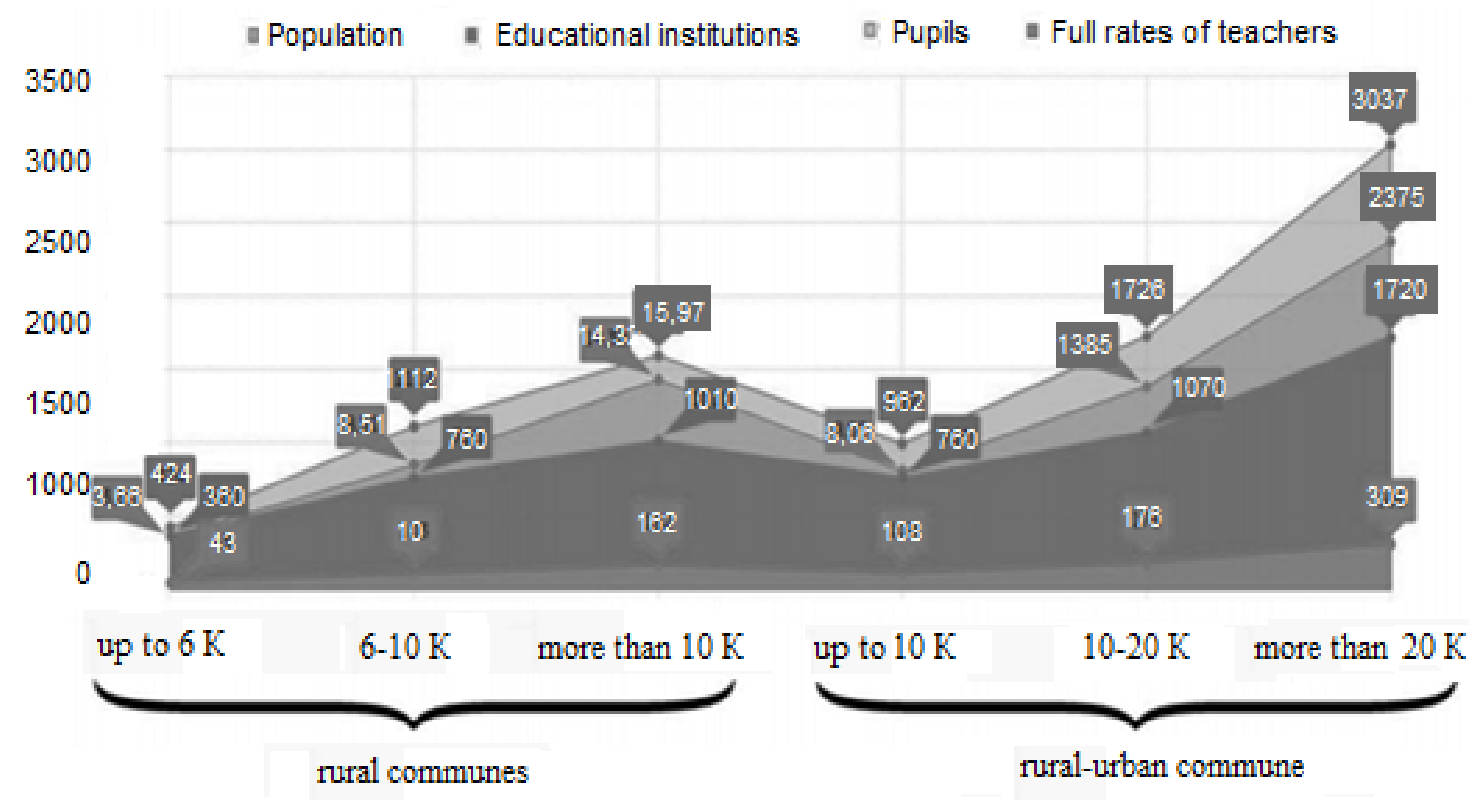

Figure 2. Indicators of educational institutions of communes

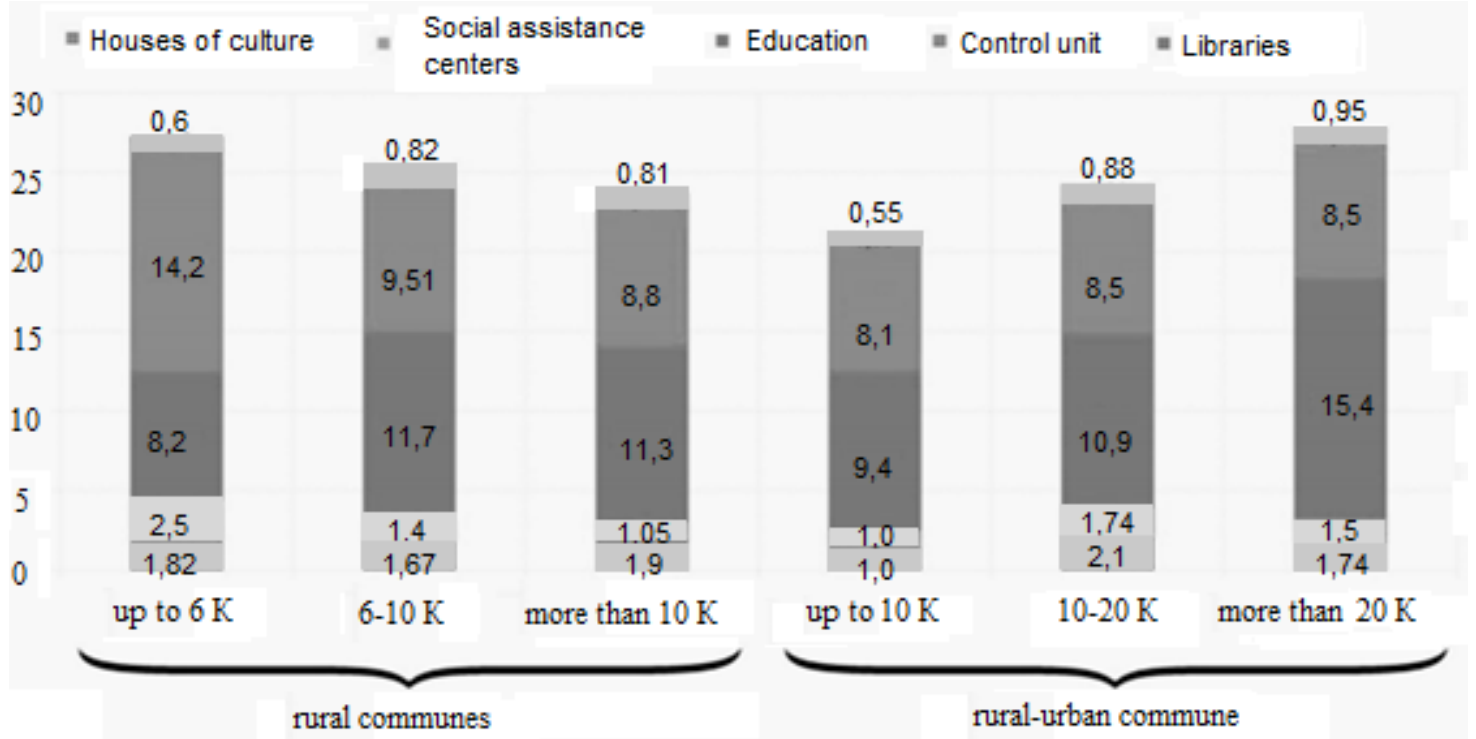

Figure 3. The structure of expenditures communes 
quality of life. The community will only be able to do so if each member of the community understands more clearly the possibilities of improving the standard of living within the community than living outside it.

Only by using as many criteria as possible a synergistic effect can be achieved, which allows the energy of the communities that have defined their position to be fully supported. After all, the main goal of local government reform is to organize people around their places of residence in such a way as to facilitate their joint activity, while improving the standard of living and quality of life for all members of the community. The community will only be able to do so if each member of the community understands more clearly the possibilities of improving the standard of living within the community than living outside it.

\section{Conclusions}

Animportantfeature of the territorialcommunity as an economic category is the existence of relations of distribution, redistribution, exchange of value of the created regional product; availability of financial relations for the formation and use of local budget indicators; participation in certain economic relations arising from the relations of ownership of joint communal property; a common economic interest in the conduct of an economic activity and the profit or loss suffered as a result of its joint and several liability; corporate rights management; participation in the formation of regional monetary funds. Also, the union of territorial communities should be based on the principle of multicriteria, since the main actors in the formation, functioning and further development of the community are people who are characterized by personal qualities that lead to interaction between members of the community, creating a cohesive team that has a common purpose and not only on the distribution of roles and places, but also on mutual support and assistance in the pursuit of a common goal, which is to develop the territorial community in order to improve the quality of life. The community will only be able to do so if each member of the community understands more clearly the possibilities of improving the standard of living within the community than living outside it. The territorial community becomes the primary subject of local self-government, the main carrier of its functions and powers. The characterization of territorial communities as the primary social actors of local authority in the field, the diversity of forms of direct and indirect democracy in local government, and the recognition of the leading role of territorial communities in shaping the whole system of public authorities (from the highest to the local), allows to determine as a special form of public authority. Local selfgovernment is a system of organizing the activities of local residents in the respective territory, which is a complex of various institutions, functioning as a single integrated mechanism, and its leading link is the territorial community.

The study has shown that there are a number of criteria, including spatial, temporal, demographic, labor, cultural, historical, financial, that should be considered when amalgamating territorial communities. Of course, taking into account the whole system of criteria is extremely difficult. However, it should be noted that only with as many criteria as possible a synergistic effect can be achieved, which allows the energy of the communities that have defined their position to be fully supported.

It is proved that as the main tools for the implementation of ATC are area, population (including demographic structure), income level, cost level, financing structure, structure of economic entities by type of activity and income level, number of social infrastructure objects, employment and unemployment rates in the community, etc. The definition of these instruments is the basis for evaluating the socioeconomic development of the community for the sake of investment attractiveness.

\section{References:}

Voevodstvo, povjat, ghmyna: decentralyzacyja kak element evropejskogho stylja [Voivodeship, county, gmina: decentralization as an element of the European style]. Available at: http://forbes.net.ua/ opinions / 1421483 -voevodstvo-povyat-gmina-decentralizaciyakak-element-evropejskogo-stilya (accessed March 19, 2020).

Ghrechana, S. I. (2017). Kartoghrafichnyj metod dlja zabezpechennja rozvytku spivpraci objednanykh terytorialjnykh ghromad [Cartographic method for securing the development of public relations of the community]. Ekonomika Ukrajiny, no. 10, pp. 65-73. 
Dolecjkyj, Z. (2001). Ghminy ta povjaty v systemi miscevogho samovrjaduvannja. Poljshhi Visnyk Ukrajinsjkoji akademiji derzhavnogho upravlinnja pry Prezydentovi Ukrajiny, no. 2, pp. 62-64. (in Ukrainian) Ustymenko, V. A., \& Zablodska, I. V. (ed.) (2018). Instytut ekonomiko-pravovykh doslidzhenj Dosvid objednannja terytorialjnykh ghromad na Skhodi Ukrajiny: ekonomiko-pravovi aspekty: kolektyvna monoghrafija [The experience of unification of territorial communities in the east of Ukraine: economic and legal aspects: collective monograph]. Kyiv: TOV «VISTKA». (in Ukrainian)

Oluiko, V. M. (ed.) (2017). Instrumenty rozvytku ob'jednanykh terytorialjnykh ghromad $v$ umovakh decentralizaciji vlady [Instruments for development of united territorial communities in the conditions of decentralization of power]. Kyiv: Vaite. (in Ukrainian)

Lendjjel, M. (2011). Misceva demokratija u krajinakh Centraljnoji ta Skhidnoji Jevropy [Local democracy in Central and Eastern Europe]. Uzhghorod: Mystecjka linija. (in Ukrainian)

Metodychni rekomendaciji shhodo ocinky rivnja spromozhnosti terytorialjnykh ghromad [Guidelines for assessing the capacity of territorial communities]. Available at: https://decentralization.gov.ua / uploads/attachment/document/478/.pdf (accessed March 19, 2020).

Pautova, T. (2011). Zabezpechennja rozvytku miscevogho samovrjaduvannja shljakhom provedennja administratyvno-terytorialinoji reformy ( $\mathrm{PhD}$ Thesis) [Ensuring the development of local self-government through administrative and territorial reform]. Donetsk: National University. (in Ukrainian)

Pro dobroviljne objednannja terytorialjnykh ghromad: Zakon Ukrajiny [On voluntary association of territorial communities: Law of Ukraine]. Available at: http://zakon0.rada.gov.ua/laws/show/157-19 (accessed March 19, 2020).

Kovbasiuk, Yu. V., Zahorodniuk, S. V., \& Prymachenko, L. V. (2012). Systema derzhavnogho upravlinnja Italijsjkoji Respubliky: dosvid dlja Ukrajiny [Public Administration System of the Italian Republic: Experience for Ukraine]. Kyiv: NADU. (in Ukrainian)

Serohin, S. M., Sharov, Yu. P., Borodin, Ye. I., \& Honcharuk, N. T. (2016). Upravlinnja strateghichnym rozvytkom objednanykh terytorialjnykh ghromad: innovacijni pidkhody ta instrumenty: monoghrafija [Managing strategic development of united territorial communities: innovative approaches and tools: monograph]. Dnipro: DRIDU NADU. (in Ukrainian)

Fedorenko, V. L., \& Chernezhenko, O. M. (2017). Konstytucijni modeli miscevogho samovrjaduvannja u derzhavakh-uchasnycjakh JeS, Shvejcariji ta Ukrajini: monoghrafija [Constitutional models of local selfgovernment in EU Member States, Switzerland and Ukraine]. Kyiv: Vydavnyctvo Lira-K. (in Ukrainian) Shymanke, D. (2008). Proektnyj dokument Systema miscevogho samovrjaduvannja ta jiji reformy. Dosvid dejakykh jevropejsjkykh krajin (Danija, Nimechchyna, Anghlija, Francija ta Shvecija) [Project document No. 12. Local self-government system and its reforms. Experience from some European countries (Denmark, Germany, England, France and Sweden)]. Kyiv, p. 28. (in Ukrainian)

Metcalf, B. (1996). Shared Visions shared Lives: Communal Living around the Globe. UK: Findhorn Press, $192 \mathrm{p}$.

NUTS - Nomenclature of territorial units for statistics. Available at: http://ec.europa.eu/eurostat/web/ nuts/overview (accessed March 19, 2020).

Ustawa z dnia 8 marca $1990 \ll$ O samorz dzie terytorialnym». Available at: http://isap.sejm.gov.pl/ DetailsServlet?id=WDU19900160095 (accessed March 19, 2020). 